\title{
REICHEL, Peter, Der schöne Schein des dritten Reiches: Faszination und Gewalt des Faschismus
}

\section{Thierry Nadau}

\section{OpenEdition}

Journals

Édition électronique

URL : http://journals.openedition.org/ifha/2046

DOI : $10.4000 /$ ifha. 2046

ISSN : 2198-8943

Éditeur

IFRA - Institut franco-allemand (sciences historiques et sociales)

Référence électronique

Thierry Nadau, «REICHEL, Peter, Der schöne Schein des dritten Reiches: Faszination und Gewalt des Faschismus », Revue de l'IFHA [En ligne], Date de recension, mis en ligne le 01 janvier 1994, consulté le 22 septembre 2020. URL : http://journals.openedition.org/ifha/2046 ; DOI : https://doi.org/10.4000/ ifha.2046

Ce document a été généré automatiquement le 22 septembre 2020.

(C)IFHA 


\title{
REICHEL, Peter, Der schöne Schein des dritten Reiches: Faszination und Gewalt des Faschismus
}

\author{
Thierry Nadau
}

1 Ce livre très riche s'intéresse au succès relatif du Troisième Reich dans son effort pour proposer une esthétique qui légitime à la fois son pouvoir et son action. La violence du système est sublimée, rendue supportable pour ceux qui n'en sont pas les victimes par un investissement systématique du champ esthétique. Ce livre reconstruit de manière très convaincante cette mise en scène, ses techniques, ses choix fondamentaux, comme l'effet de masse et la théatralisation. Cela conduit l'auteur à définir cette culture comme une culture kitsch parce qu'elle associe beauté et pouvoir dans une mise en scène triviale qui exploite les ressources de la modernité tout en refusant son extrémisme. Ou comment le nazisme sut être un régime de consensus.

Thierry NADAU 